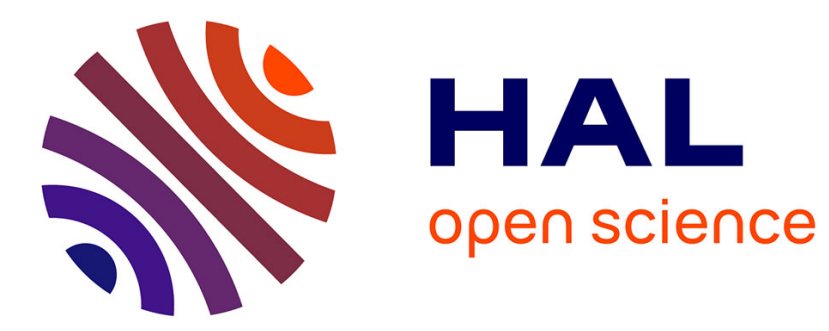

\title{
Diversity and safety hazards of bacteria involved in meat fermentations
}

\author{
Régine Talon, Sabine Leroy
}

\section{To cite this version:}

Régine Talon, Sabine Leroy. Diversity and safety hazards of bacteria involved in meat fermentations. Meat Science, 2011, 89 (3), pp.303-309. 10.1016/j.meatsci.2011.04.029 . hal-02651367

\section{HAL Id: hal-02651367 https://hal.inrae.fr/hal-02651367}

Submitted on 29 May 2020

HAL is a multi-disciplinary open access archive for the deposit and dissemination of scientific research documents, whether they are published or not. The documents may come from teaching and research institutions in France or abroad, or from public or private research centers.
L'archive ouverte pluridisciplinaire HAL, est destinée au dépôt et à la diffusion de documents scientifiques de niveau recherche, publiés ou non, émanant des établissements d'enseignement et de recherche français ou étrangers, des laboratoires publics ou privés. 
Review

\title{
Diversity and safety hazards of bacteria involved in meat fermentations
}

\author{
Régine Talon *, Sabine Leroy \\ INRA, UR454 Microbiologie, F-63122 Saint-Genès Champanelle, France
}

\section{A R T I C L E I N F O}

Article history:

Received 22 March 2011

Received in revised form 20 April 2011

Accepted 27 April 2011

\section{Keywords:}

Safety hazards

Lactic acid bacteria

Coagulase negative staphylococci

Sausages

\begin{abstract}
A B S T R A C T
Food safety is a major concern for consumers and a major issue for industry which has become aware of the importance of the starter safety assessment. In the European Union, the Food Safety Authority has introduced the Qualified Presumption of Safety (QPS) approach for safety assessment of microorganisms throughout the food chain. This assessment relies on: taxonomy, familiarity, pathogenicity and end use. Productions of toxins as well as biogenic amines by food isolates are both of major concern as they can lead to food poisoning. The other important criterion is the presence of transmissible antibiotic resistance markers. This review underlined that the main hazard of bacteria involved in food fermentations concerns antibiotic resistance and particularly the presence of transferable genetic determinants that may present a risk for public health. Selection of starter strains should consider this hazard. Following the QPS approach, a list of bacteria has been acknowledged acceptable for consumption.
\end{abstract}

\section{Contents}

1. Introduction . . . . . . . . . . . . . . . . . . . . . . . . . . . . . . . . . . . . . . . 303

2. Inventory of bacteria with a history of use in meat products . . . . . . . . . . . . . . . . . . . . . . . . . . . . . . . . . 304

3. Are there safety concerns for meat-associated lactic acid bacteria and coagulase negative staphylococci? . . . . . . . . . . . . . 305

3.1. Toxin production . . . . . . . . . . . . . . . . . . . . . . . . . . . . . . . . . . . . . . . . . 305

3.2. Biogenic amine production . . . . . . . . . . . . . . . . . . . . . . . . . . . . . . . . . . . . . . 305

3.3. Antibiotic resistance. . . . . . . . . . . . . . . . . . . . . . . . . . . . . . . . . . . . 306

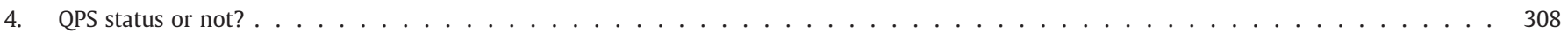

Acknowledgement . . . . . . . . . . . . . . . . . . . . . . . . . . . . . . . . . . . . . . . . . . 308

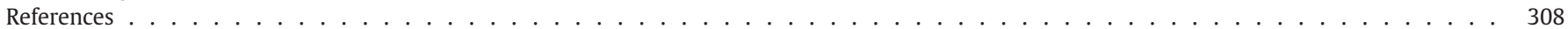

\section{Introduction}

The technology for producing fermented foods has been known since ancient times in most parts of the world. Originally the fermentation of these foods only relied on indigenous microbiota but the inoculation of microorganisms has been applied for the past 100 years. The extensive use of starter cultures dates backed to the middle of the 20th century. In fermented meat products, pasteurisation of raw materials is not desirable, thus fermentation relies either only on "house flora" for traditional products or on starter cultures for artisanal and industrial sausages which must be competitive to prevent outgrowth of indigenous bacteria (Leroy, Verluyten, \& De Vuyst, 2006).

\footnotetext{
* Corresponding author. Tel.: + 33473624 170; fax: + 33473624581 . E-mail address: regine.talon@clermont.inra.fr (R. Talon).
}

Food safety is still a major concern for consumers and a major issue for industry which has become aware of the importance of the starter safety assessment. In contrast to the European Union (EU) regulation on microorganisms entering the food chain in association with animal feeds or as plant protection products, there are no recognised means for microorganisms to be formally considered safe when used for human food preparation. The widely know standard is the GRAS status (Generally Recognised as safe) from the US Food Drug Administration (FDA) which has a list of microorganisms considered safe for a specific use (Chamba \& Jamet, 2008). In the EU, a similar approach has been proposed by the European Food Safety Authority (EFSA, Regulation (EC) $n^{\circ} 178 / 2002$ ). This authority has introduced the Qualified Presumption of Safety (QPS) approach for safety assessment of microorganisms throughout the food chain (EFSA, 2004). The safety assessment relies on four pillars: taxonomy, familiarity, pathogenicity and end use (EFSA, 2005a). The term 'familiarity' or 'body of knowledge' includes history of use, ecology, 
industrial applications and scientific literature. The degree of familiarity is obviously higher for microorganisms widely used for several decades. The International Dairy Federation (IDF) in collaboration with the European Food and Feed Cultures Association (EFFCA) has listed the microorganisms with a documented history of use in human food at international level (Mogensen et al., 2002). The EFSA has also established a list of microorganisms proposed for QPS status (EFSA, 2004).

\section{Inventory of bacteria with a history of use in meat products}

The first step in the QPS assessment is to establish the precise identity of the microorganism at genus and species levels and if relevant at the subspecies and strain levels.

In meat fermentation two main groups of bacteria are considered important: the lactic acid bacteria (LAB) and the coagulase-negative staphylococci (CNS). The initial population of LAB is usually low in the raw material ( 3 to $4 \log \mathrm{CFU} / \mathrm{g}$ ) but it becomes dominant during the fermentation step ( $8 \log \mathrm{CFU} / \mathrm{g}$ ) in traditional sausages (Comi et al., 2005; Greco, Mazette, De Santis, Corona, \& Cosseddu 2005; Lebert et al. 2007). LAB contribute to sausage sensorial properties mainly through their acidification (Leroy et al., 2006). The development of a functional microarray dedicated to LAB and targeting genes that play key roles in sugar catabolism, in the production of bacteriocins, exopolysaccharides and flavour will allow characterising the LAB dynamics in complex sausage ecosystems (Weckx et al., 2009). CNS frequently represent the second population varying from 5 to $7 \log$ CFU/g in traditional sausages (Blaiotta et al. 2004b; Corbière Morot-Bizot, Leroy, \& Talon 2006; Iacumin, Comi, Cantoni, \& Cocolin 2006; Mauriello, Casaburi, Blaiotta, \& Villani 2004). They participate to the development and stability of the colour and contribute to the flavour through their antioxidant properties and amino acid catabolism (F. Leroy et al., 2006; Talon, Leroy-Sétrin, \& Fadda 2002). Similarly, the development of a DNA microarray for CNS targeting genes involved in technological properties such as the ones coding for proteases, lipases, nitrate dissimilation, catalase and superoxide dismutase will allow to characterise their expression in situ in sausages (Seitter, Nerz, Rosenstein, Götz, \& Hertel 2011).

In the last decade, the development of molecular methods has allowed reliable identification of staphylococci (Aymerich, Martin, Garriga, \& Hugas 2003; Corbière Morot-Bizot, Talon, \& Leroy 2004; Giammarinaro, Leroy, Chacornac, Delmas, \& Talon 2005) and LAB (Aymerich et al., 2006; Rantsiou et al., 2005). Moreover, combining the study of the microbial ecology by culture-dependent and -independent methods has contributed to a better understanding of microbial dynamics during sausage manufacturing (Rantsiou \& Cocolin, 2006).

The main LAB genera isolated from fermented dry sausages are Lactobacillus, Pediococcus, Leuconoctoc, Weissella and Enterococcus (Albano et al., 2009; Ammor \& Mayo, 2007). Usually Lactobacillus species are dominant in sausages, however in some slightly acidified sausages from southern Europe, Enterococcus and Lactobacillus species cohabit (Lebert et al., 2007; Martin, Garriga, Hugas, \& Aymerich 2005). Among lactobacilli, Lactobacillus sakei, Lactobacillus curvatus and/or Lactobacillus plantarum generally constitute the predominant microbiota during traditional sausage ripening (Bonomo, Ricciardi, Zotta, Parente, \& Salzano 2008; Cocolin et al., 2009; Lebert et al., 2007; Silvestri et al., 2007). Other lactobacilli that may be found at minor levels include Lactobacillus pentosus, Lactobacillus paracasei, Lactobacillus casei and Lactobacillus alimentarius (Aymerich et al., 2006; Comi et al., 2005; Greco et al., 2005; Papamanoli, Tzanetakis, LitopoulouTzanetaki, \& Kotzekidou 2003; Rantsiou et al., 2005). Enterococcus faecium and Enterococcus faecalis were the most frequently isolated species from two slightly fermented Spanish sausages (Martin et al., 2005). Pediococci are less frequently isolated from European sausages except from Iberian dry fermented sausages and Chorizo (Benito et al.,
2007; Benito et al., 2008) and certain Italian sausages (Bonomo et al., 2008). They are more common in fermented sausages from the United States where Pediococcus acidilactici and Pediococcus pentosaceus are added as starter cultures (F. Leroy et al., 2006). In the EU, L. sakei, $L$. curvatus, L. plantarum and L. pentosus are the species most commonly used as starter culture in sausage manufacturing (Ammor \& Mayo, 2007; Talon et al., 2002). A high biodiversity at strain level inside the predominant species has been reported. The clustering analysis of 295 LAB isolates from different kinds of sausages produced in Hungary, Italy, and Greece gave 5 different clusters for the 27 isolates of $L$. plantarum, 9 clusters for the 100 isolates of L. curvatus and 19 clusters for the 168 isolates of $L$. sakei (Rantsiou et al., 2005). Aymerich et al. (2006) were able to distinguish 144 different RAPD/plasmid profiles among 250 LAB isolates from 21 different Spanish slightly fermented sausages with $L$. sakei showing 112 different strains out of 185 isolates. An intraspecies diversity among 73 isolates of $L$. sakei sourced from different countries was determined using a PCR-based method that detects the possession of 60 chromosomal genes belonging to the flexible gene pool. Ten different strain clusters were identified and many different genotypes may be isolated from similar types of meat products, suggesting a complex ecological habitat in which intraspecies diversity may be required for successful adaptation (Chaillou et al., 2009).

The species used as starter cultures belonging to the Lactobacillus and Pediococcus genera have a long history of apparent safe use in industrial meat applications. Some species are also used in a variety of food fermentation such as dairy products ( $P$. acidilactici), fermented vegetables, sourdough and silage ( $L$. plantarum) (Mogensen et al., 2002). Moreover and as mentioned above, some species are among the dominant population in microbial communities of traditional fermented sausages, being part of the natural starter cultures. Unlike the two genera mentioned above, the enterococci have the paradoxal position of being considered positive for meat and dairy fermentation but also constitute a potential risk (Hugas, Garriga, \& Aymerich 2003; Ogier \& Serror, 2008). Thus numerous attempts have been done to type the isolates of $E$. faecalis and E. faecium from different origins. The strains typing of 106 enterococci isolates from fermented sausages revealed that 60 strains exhibited different RAPD profiles indicating a high genetic variability (Martin et al., 2005). Pulse field gel electrophoresis (PFGE) analysis has been successfully used to differentiate between clinical and food isolates of $E$. faecalis and $E$. faecium (Ogier \& Serror, 2008). Multilocus sequence typing and multilocus variable analyses applied to 411 isolates of $E$. faecium from different continents and ecological niches have revealed that most of derived vancomycin-resistant enterococci are part of a single clonal lineage (Willems et al., 2005). In spite of the wide range of molecular typing it remains difficult to clearly differentiate food and clinical isolates.

The staphylococcal ecosystem of traditional dry fermented sausages is diverse with many species cohabiting. However, Staphylococcus xylosus, Staphylococcus equorum and Staphylococcus saprophyticus are the three prevalent species (Bonomo, Ricciardi, Zotta, Sico, \& Salzano 2009; Cocolin, Manzano, Aggio, Cantoni, \& Comi 2001; Coton et al., 2010; Mauriello et al., 2004; Leroy, Giammarinaro, Chacornac, Lebert, \& Talon 2010). A wide diversity among minor species could be found, e.g. up to 15 species identified in French traditional sausages (S. Leroy et al., 2010) but Staphylococcus succinus, Staphylococcus carnosus, Staphylococcus warneri and Staphylococcus epidermidis are frequently reported (Aymerich et al., 2003; Corbière Morot-Bizot et al., 2006). Among CNS, only S. carnosus and S. xylosus species are used as starter cultures for manufacturing dry sausages in the EU (Corbière Morot-Bizot, Leroy, \& Talon 2007). The natural habitat of CNS is the skin and the mucous membranes of animals and humans (Irlinger, 2008). Foods constitute a man-made habitat in which intentionally added and naturally occurring CNS may grow and modify their sensorial characteristics. CNS are isolated from a wide 
range of foods from animal origin such as meat and meat products, milk and cheese (Blaiotta et al. 2004b; Irlinger, 2008; S. Leroy et al., 2010; Martin et al., 2006). It is noteworthy than the three prevalent species in fermented sausages, S. xylosus, S. equorum and $S$. saprophyticus, were also frequently isolated from various cheeses (Coton et al., 2010).

The infraspecies of food CNS have been characterised and high genetic diversity was revealed by PFGE analysis of isolates from cheeses and meat products of $S$. saprophyticus, S. equorum and $S$. xylosus (Coton et al., 2010, S. Leroy et al., 2009; Rossi, Tofalo, Torriani, \& Suzzi 2001; Villard et al., 2003). For example, the diversity of strains of $S$. equorum isolated from traditional French sausages and their manufacturing environments have been highlighted with 52 profiles for 118 isolates and 28 profiles for 71 isolates (S. Leroy et al., 2009, S. Leroy et al., 2010). Moreover theses two studies revealed that the diversity was maintained throughout the process. As some species found in food could be involved in human or animal infections, comparison of PFGE profiles has been carried out. High genetic diversity was revealed and no common profile was found between isolates from food and clinical samples of $S$. saprophyticus and S. epidermidis (Coton et al., 2010). S. xylosus strains of food and mastitis origins were genetically clearly distinct (Dordet-Frisoni, Dorchies, De Araujo, Talon, \& Leroy 2007).

\section{Are there safety concerns for meat-associated lactic acid bacteria and coagulase negative staphylococci?}

Lactobacilli and pediococci have generally been considered to be non-pathogenic. Species of these genera have been occasionally encountered in clinical specimens usually affecting immunocompromised patients (Bernardeau, Vernoux, Henri-Dubernet, \& Gueguen 2008).

Enterococci have been involved in nosocomial infections, in particular E. faecalis and E. faecium, two species commonly isolated from food products and in fermented meats (Ogier \& Serror 2008). For CNS, S. xylosus and S. equorum two dominant species in meat products have rarely been associated with clinical cases (Irlinger, 2008; Novakova et al., 2006). S. saprophyticus frequently isolated from meat products is associated with urinary tract infections (Piette \& Verschraegen, 2009) and S. epidermidis episodically isolated is associated with nosocomial infections (Stevens et al., 2008).

It is worth noting that CNS and enterococci species associated with clinical cases have not been reported to be associated with food consumption (Irlinger, 2008; Ogier \& Serror, 2008). However, the occurrence and the pathogenic potential of some species including species isolated from food reinforce the need to assess the safety of the food isolates.

In the food context, productions of toxins as well as biogenic amines by food isolates are both of major concern as they can lead to food poisoning. The other important criterion in the evaluation of strain safety is the presence of transmissible antibiotic resistance markers.

DNA microarrays have been developed to characterise these safety hazards. For CNS, two microarrays have been developed, one with 268 genes targeting only safety hazards (Even et al., 2010), and the other with 220 genes targeting safety hazards and technological properties (Seitter et al., 2011). Similarly a functional microarray dedicated to LAB has been developed to screen safety hazards in particular antibiotic resistance (Weckx et al., 2009).

\subsection{Toxin production}

Staphylococcal intoxication worldwide stands out as one of the main food-borne diseases. For many years, staphylococcal food poisoning was uniquely associated with coagulase positive Staphylococcus aureus and its production of staphylococcal enterotoxins (SEs).
Nine major antigenic types of SEs have been reported: the classical five SEA to SEE and the four additional SEG to SEJ (Blaiotta et al. 2004a; Le Loir, Baron, \& Gautier 2003). Detection of nine additional genes (seK to seR and seU) coding homologous enterotoxins expanded the SE family (Blaiotta et al. 2004a). Furthermore for SEC, SEG, SEI and SEU several variants were also reported. No relationship between these new SEs and human food poisoning has been described as yet.

Staphylococcal enterotoxins have been studied in CNS isolated from food. Recent studies either by PCR and/or DNA microarrays revealed that the occurrence of SEs genes in CNS isolated from meat products, milk and cheeses was very rare. No enterotoxins genes were detected in large collections of 87 and 128 CNS strains of S. equorum, S. xylosus and S. saprophyticus (Blaiotta et al. 2004a; Even et al., 2010). Similarly, no SE genes were found in 32 CNS strains including $S$. equorum, S. xylosus and S. carnosus species (Seitter et al., 2011). By PCR and immunoassay, Rosec, Guiraud, Dalet, and Richard (1997) showed that 51 CNS strains isolated from various foods did not produce enterotoxins SEA to SEE. These results contrast with previous works pointing out CNS strains that produce enterotoxins. In particular, seven out of the 32 strains studied by Seitter et al. (2011) have been shown to produce enterotoxins by immunoblot analysis, with SED and SEH being the most commonly produced, mainly by S. equorum strains (Zell et al., 2008). By immunoassay, few strains of CNS isolated from dry cured Spanish ham were able to produce enterotoxin C and/or D: one S. xylosus, one S. cohnii and one S. epidermidis (Rodriguez, Nunez, Cordoba, Bermudez, \& Asensio 1996). Still by immunoassay, few CNS, identified at the species level by phenotypic methods, isolated from sheep milk or from goat milk and cheese were shown to produce classical enterotoxins (Bautista, Gaya, Medina, \& Nunez 1988; Vernozy-Rozand et al., 1996).

Enterotoxigenic capacity of CNS has always been a subject of controversy. Methods used for screening might account for discrepancies between results relying on detection of SE production by immunological methods and results based on the presence of the corresponding genes. Immunoassays to detect enterotoxins have been reported to lead false diagnoses due to interferences, lack of specificity and/or sensitivity (Dupuis, Hennekinne, Garin, \& Brun 2008). In accordance, SE detection based on immunological approaches is not always confirmed by DNA-based tests and vice versa (Rodriguez et al., 1996; Seitter et al., 2011; Zell et al., 2008). Besides, one cannot exclude the existence of enterotoxin gene variants (diverging from $S$. aureus sequences) in CNS species (although no such variant has been described so far), which are not detected by microarrays or by PCR. However, no case of food poisoning involving exclusively strains of CNS of food origin has been reported so far.

Further investigation of the toxigenic potential of CNS revealed that haemolytic activity could be detected. From a collection of 330 CNS isolated from food including fermented and cured meats and meat starter cultures, $59 \%$ of the strains exhibited weak to moderate haemolytic activity with human blood (Zell et al., 2008) but only weak hybridization signals were obtained with 3 strains for $h l b$ gene coding $\delta$-hemolysin (Seitter et al., 2011). Presence of $h l b$ gene was detected in 5 strains by microarrays but only one S. epidermidis was confirmed by PCR (Even et al., 2010).

In conclusion, food related CNS exhibit low toxigenic and enterotoxigenic potential. Acquisition by CNS strains of genes encoding toxins from $S$. aureus or other Gram-positive bacteria sharing the same ecosystem appeared to be very limited (Even et al., 2010), even if some of these toxins, especially enterotoxins, are carried by mobile genetic elements (Baba et al., 2002).

\subsection{Biogenic amine production}

Among food safety hazards associated with LAB and CNS, the potential production of biogenic amines has to be considered. Biogenic amines are generated in various fermented foods through 
bacterial amino acid decarboxylation. Cadaverine, histamine, putrescine, tryptamine, tyramine and phenylethylamine are regarded as undesirable because of their toxic effects. From a toxicological aspect, the vasoactive and psychoactive effects of amines are related to the occurrence of histaminic intoxication, food-induced migraines and hypertensive crises in sensitive individuals (Suzzi \& Gardini, 2003). In such people, the action of amine oxidases, the enzymes involved in the detoxification of these substances are deficient (Suzzi \& Gardini, 2003). A regulation is already in force in the fish industry in EU and may be extended to fermented food in the future.

The content of biogenic amines can be relatively high in fermented food, especially in raw materials (meat and dairy products) presenting a high content of proteins combined with high proteolytic activity (Suzzi \& Gardini, 2003). Such a situation is met in dry sausages where many studies reported variable level of amines (Ansorena et al., 2002; Latorre-Moratalla et al., 2008). A lot of information concerns the production of biogenic amines by LAB. Some LAB (48\%) isolated from dry fermented sausages decarboxylated one or more amino acids (Latorre-Moratalla et al., 2010). Aminogenic potential is species and strain dependent. Most L. curvatus, E. faecium and E. faecalis strains isolated from dry fermented sausages produced tyramine and phenylethylamine whereas all the $L$. sakei strains were nonaminogenic (Aymerich et al., 2006; Bover-Cid, Hugas, Izquierdo-Pulido, \& Vidal-Carou 2001; Hugas et al. 2003; Latorre-Moratalla et al., 2010). Enterococci isolated from cheese have been described as tyramine and tryptamine producers and production of biogenic amines in milk has also been observed (Garg \& Mital, 1991).

By comparison, biogenic amine production by CNS in fermented products is poorly documented. It has never been described in dairy products and only few studies reported their production by CNS isolated from meat products (Martín et al., 2006). The percentage of CNS able to produce detectable amounts of biogenic amines is low and varied from 6\% to 14\% (Even et al., 2010; Latorre-Moratalla et al., 2010; Martín et al., 2006). The described aminogenic strains belong to S. xylosus, S. warneri, S. epidermidis and S. carnosus. Phenylethylamine was the amine the most frequently produced followed by tyramine (Martín et al., 2006).

In conclusion, selection of LAB and to a lesser extent of CNS, to be used as starter cultures for sausage production should consider the criteria of absence of amino decarboxylase activity.

\subsection{Antibiotic resistance}

Antibioresistance of food bacteria has aroused great interest because they may act as reservoirs for antibiotic resistance genes. Fermented foods may be important vehicles of high amounts of living bacteria into the human body. They may carry transferable antibiotic resistances, which might be transferred to commensal or pathogenic bacteria. Therefore, the presence of transmissible antibiotic resistance genes in the evaluation of strains is an important safety criterion.

Antibiotic resistance trends among $E$. faecalis and $E$. faecium have been extensively investigated, in particular in clinical and human isolates. E. faecium clinical isolates are intrinsically resistant to penicillin and have acquired genetic determinants conferring resistance to glycopeptides (vancomycin, teicoplanin) and to synergic action of $\beta$-lactams and aminoglycosides (Ogier \& Serror, 2008). Although antibiotic resistant enterococci are isolated from foods, only few are resistant to clinically important antibiotics ampicillin, penicillin, gentamicin and vancomycin (Martín et al., 2006; Ogier \& Serror, 2008).

Resistance to rifampicin, ciprofloxacin and erythromycin was observed in most E. faecalis and E. faecium strains isolated from fermented sausages. Furthermore, E. faecalis strains were resistant to chloramphenicol (93\%) and tetracycline (87\%), whereas E. faecium strains showed higher incidence of penicillin and ampicillin resistances (Martín et al., 2006). Resistances to chloramphenicol, erythromycin and tetracycline were already noticed for dairy $E$. faecalis isolates (Teuber, Meile, \& Schwarz 1999). The frequent detection of antibiotic resistance among food enterococci is probably due to the efficient transfer mechanisms of resistance genes via conjugative plasmids and transposons. For example tetracycline resistance $\left(\mathrm{Tet}^{\mathrm{r}}\right)$ is one of the most commonly acquired forms of antibiotic resistance in food enterococci isolates. Huys, D'Haene, Collard, and Swings (2004) showed that $\operatorname{Tet}^{\mathrm{r}}$ in food enterococci is mainly conferred by the same tet determinants (tetM, tetL, tetS) as those previously found in clinical and veterinary isolates. These authors showed also that a significant proportion of $\mathrm{Tet}^{\mathrm{r}}$ isolates exhibited co-resistance to erythromycin and/or chloramphenicol suggesting that $\operatorname{Tet}^{\mathrm{r}}$ genes are associated with transposons carrying multiple antibioresistance genes (Huys et al., 2004). During the past years, several studies have reported antibiotic resistance gene transfers i) in laboratory conditions between clinical, commensal, food and probiotic isolates (Lund \& Edlund, 2001), ii) in food matrix : cheese and sausage (Cocconcelli, Cattivelli, \& Gazzola 2003) and iii) in gnotobiotic mice (Moubareck, Bourgeois, Courvalin, \& DoucetPopulaire 2003). Recently, a transfer of vanA gene has been showed between Enterococcus strains in the digestive tract of mice colonised by human microbiota (Mater, Langella, Corthier, \& Flores 2005). The transfer of resistance gene from E. faecalis to pathogenic species has been demonstrated for $S$. aureus in a cutaneous mouse model and Listeria monocytogenes in vitro (Biavasco et al., 1996). Moreover, gene transfer has been implicated in the emergence of vancomycin- and methycillin-resistant S. aureus (Tenover \& McDonald, 2005).

Generally, LAB belonging to the genera Lactobacillus, Streptococcus, Lactococcus, Pediococcus and Leuconostoc have a high natural resistance to ciprofloxacin, gentamicin and streptomycin indicating that these may constitute intrinsic resistance (Table 1). LAB are generally sensitive to erythromycin, chloramphenicol, tetracycline or $\beta$-lactams (Aymerich et al., 2006; Hummel, Hertel, Holzapfel, \& Franz 2007). All L. sakei and L. curvatus meat strains were resistant to vancomycin (Aymerich et al., 2006) (Table 1). Such resistance was also described for L. plantarum, L. casei, L. salivarius and L. acidophilus that have intrinsic resistance to this drug (Bernardeau et al. 2008). However, some data highlighted the presence of transferable antibioresistance genes. Tetracycline resistance gene, in particular tetM, localised in a plasmid has been identified in $L$. sakei, $L$. alimentarius and $L$. plantarum strains isolated from fermented sausages (Gevers et al., 2003) and tetM residing in a plasmid was found in Lactobacillus reuteri and Bifidobacterium lactis, two probiotic cultures (Kastner et al., 2006). Recently, strains belonging to L. sakei, $L$. curvatus and L. plantarum isolated from Italian fermented sausages were found resistant to tetracycline with tetM gene most frequently detected but tetW was also detected (Table 1) (Zonenschain, Rebecchi, \& Morelli 2009). The tetM gene can also be linked to a family of transposons known for its ability to perform conjugative transposition with direct transfer between different bacteria (Sorum \& L'Abee-Lund, 2002). These strains were also resistant to erythromycin mainly associated to the presence of the ermB gene (Table 1) (Zonenschain et al., 2009).

The most frequent resistances found in CNS of food origin were those to ampicillin, erythromycin, penicillin, lincomycin and tetracycline (Table 2). The incidence of resistance in food CNS varied strongly between strains, ranging from a complete lack of resistance (56\%) to resistance up six antibiotics: 2.3\% of strains for Even et al. (2010) and $7 \%$ of strains for Resch, Nagel, and Hertel (2008). Multi-resistance of CNS isolated from meat or sausage has been also reported by Mauriello, Moschetti, Villani, Blaiotta, and Coppola (2000) and Simeoni et al. (2008). The incidence of antibiotic resistance was also found to be species-dependent: resistance to at least one antibiotic was observed in $36 \%$ and $26 \%$ of S. xylosus and S. equorum strains, respectively (Even et al., 2010). Resch et al. (2008) found 12\% of $S$. carnosus, $63 \%$ of S. equorum and $95 \%$ of S. xylosus resistant to 
Table 1

Prevalence of antibiotic resistance in food-associated LAB (except enterococci).

\begin{tabular}{|c|c|c|c|c|}
\hline Main species (number of strains) & Origin & Main antibiotic resistance (\%) & Antibiotic-resistant genes (\%) & Reference \\
\hline $\begin{array}{l}\text { Lactobacillus, Streptococcus, Lactococcus, } \\
\text { Pediococcus, Leuconostoc (40) }\end{array}$ & $\begin{array}{l}\text { Fermented sausage, } \\
\text { cheese, yogurt }\end{array}$ & $\begin{array}{l}\text { Gentamicin (71) } \\
\text { Streptomycin (73) } \\
\text { Ciprofloxacin (78) }\end{array}$ & & Hummel et al.(2007) \\
\hline $\begin{array}{l}\text { L. curvatus ( } 3), \text { L. alimentarius ( } 3) \text {, } \\
\text { L. plantarum (8), L. sakei (10) }\end{array}$ & Fermented sausage & Tetracycline (100) & tetM (100) & Gevers et al. (2003) \\
\hline L. curvatus (53) & Fermented sausage & $\begin{array}{l}\text { Gentamicin (100) } \\
\text { Vancomycin (100) } \\
\text { Ampicillin (15) } \\
\text { Penicillin (11) } \\
\text { Tetracycline (13) }\end{array}$ & ND & Aymerich et al.(2006) \\
\hline L. curvatus (16) & Fermented sausage & $\begin{array}{l}\text { Tetracycline (62) } \\
\text { Erythromycin (62) }\end{array}$ & $\begin{array}{l}\text { tetM }(70), \text { tetW }(40) \\
\operatorname{erm} B(100)\end{array}$ & Zonenschain et al.(2009) \\
\hline L. plantarum (12) & Fermented sausage & $\begin{array}{l}\text { Tetracycline }(92) \\
\text { Erythromycin (50) }\end{array}$ & $\begin{array}{l}\text { tetM (45), tetW (36), tetS (9) } \\
\operatorname{ermB}(50), \operatorname{ermC}(33)\end{array}$ & Zonenschain et al.(2009) \\
\hline L. sakei (185) & Fermented sausage & $\begin{array}{l}\text { Gentamicin (100) } \\
\text { Vancomycin (100) } \\
\text { Ampicillin (52) } \\
\text { Penicillin (33) } \\
\text { Tetracycline (11) }\end{array}$ & ND & Aymerich et al.(2006) \\
\hline L. sakei (24) & Fermented sausage & $\begin{array}{l}\text { Tetracycline (71) } \\
\text { Erythromycin (29) }\end{array}$ & $\begin{array}{l}\text { tetM (64), tetW (9) } \\
\operatorname{ermB}(71)\end{array}$ & Zonenschain et al.(2009) \\
\hline L. mesenteroides (12) & Fermented sausage & $\begin{array}{l}\text { Gentamicin (67) } \\
\text { Vancomycin (100) } \\
\text { Ampicillin (42) } \\
\text { Penicillin (50) } \\
\text { Tetracycline (25) }\end{array}$ & ND & Aymerich et al.(2006) \\
\hline
\end{tabular}

ND: not done.

antibiotics. Comparison of the antibiotic resistance profiles established by phenotypic approach with either microarray or PCR data enabled assigning genes putatively involved in most antibiotic resistances. In most studies, resistances to penicillin, tetracyclin, lincomycin and erythromycin were traced back to the presence of genes blaZ, tetK but also tetM, InuA, ermB and ermC (Table 2). Normally bla genes coding $\beta$-lactamases are in transposons located on small transferable or mobilisable plasmids (Sorum \& L'Abee-Lund, 2002). The high incidence of tetK and tetM genes can be explained as mentioned above by their location on small multicopy plasmids and on conjugative transposons, respectively, which contribute to the spread of these determinants. Similarly, ermC gene is located on small multicopy plasmids while ermB is often carried by conjugative transposons, these locations explaining their spread (Simeoni et al.,

Table 2

Prevalence of antibiotic resistance in food-associated CNS.

\begin{tabular}{|c|c|c|c|c|}
\hline Main species (number of strains) & Origin & Main antibiotic resistance (\%) & $\begin{array}{l}\text { Antibiotic-resistant genes } \\
(\%)\end{array}$ & Reference \\
\hline S. carnosus (11) & Fermented sausage & $\begin{array}{l}\text { Ampicillin (100) } \\
\text { Penicillin (27) }\end{array}$ & ND & Martin et al.(2005) \\
\hline S. carnosus (106) & Meat starter culture, fermented fish & Lincomycin (6) & None & Resch et al.(2008) \\
\hline S. equorum (64) & Cured ham, fermented sausage, hard and soft cheese & $\begin{array}{l}\text { Lincomycin (48), } \\
\text { Oxacillin (19) }\end{array}$ & None & Resch et al.(2008) \\
\hline S. equorum (31) & Fermented sausage, cheese & $\begin{array}{l}\text { Erythromycin (20) } \\
\text { Tetracycline (10) }\end{array}$ & $\begin{array}{l}\text { None } \\
\text { tetK (100) }\end{array}$ & Even et al.(2010) \\
\hline S. xylosus (30) & Fermented sausage & $\begin{array}{l}\text { Penicillin (90) } \\
\text { Erythromycin (30) } \\
\text { Lincomycin (93) } \\
\text { Fusidic acid (73) } \\
\text { Tetracycline (20) }\end{array}$ & ND & $\begin{array}{l}\text { Mauriello et al. } \\
\text { (2000) }\end{array}$ \\
\hline S. xylosus (194) & Fermented sausage & $\begin{array}{l}\text { Penicillin (82) } \\
\text { Ampicillin (69) } \\
\text { Erythromycin (36) }\end{array}$ & ND & Martin et al. (2005) \\
\hline S. xylosus (33) & Fermented sausage & $\begin{array}{l}\text { Penicillin (9) } \\
\text { Nalidixic acid (9) } \\
\text { Tetracycline (12) }\end{array}$ & $\begin{array}{l}\text { None } \\
\text { None } \\
\text { tetK }(100)\end{array}$ & Kastner et al.(2006) \\
\hline S. xylosus (137) & $\begin{array}{l}\text { Meat starter culture, fermented sausage, cured ham, } \\
\text { hard and soft cheese milk }\end{array}$ & $\begin{array}{l}\text { Penicillin (69), } \\
\text { Oxacillin (41), } \\
\text { Ampicillin (48) } \\
\text { Lincomycin (53), } \\
\text { Fusidic acid (50), } \\
\text { Tetracycline (36) }\end{array}$ & $\begin{array}{l}\operatorname{blaZ}(10) \\
\operatorname{lnuA}(2) \\
\operatorname{tetK}(100)\end{array}$ & Resch et al.(2008) \\
\hline S. xylosus (12) & Pig feedstuff, meat, fermented sausage & $\begin{array}{l}\text { Tetracycline } \\
\text { Erythromycin } \\
\text { Penicillin }\end{array}$ & $\begin{array}{l}\text { tetK }(67), \text { tetM }(50), \\
\operatorname{ermB}(83), \text { ermC }(41) \\
\operatorname{blaZ}(33)\end{array}$ & Simeoni et al., 2008 \\
\hline S. xylosus (28) & Fermented sausage, cheese & $\begin{array}{l}\text { Penicillin (32) } \\
\text { Tetracycline (17) }\end{array}$ & $\begin{array}{l}\text { blaZ }(100) \\
\text { tetK }(100)\end{array}$ & Even et al.(2010) \\
\hline
\end{tabular}

ND: not done; none: resistance gene not found. 
2008). However discrepancies between phenotypic antibiotic resistance and molecular determinant have often been reported (Even et al., 2010; Hummel et al., 2007; Seitter et al., 2011). Some genes may be present as pseudogenes but also some antibiotic resistances are due to complex intrinsic features such as cell wall structure or metabolic properties (Kastner et al., 2006). They may also be related to point mutations as for macrolide, quinolone, rifampicin and fusidic acid resistances (Even et al., 2010).

From this review, it appears that most antibiotic resistances are shared by the different food bacteria. The sequencing of several antibiotic resistance genes and of the genetic vectors responsible for mobility (transposons, plasmids) showed identity in their sequences independently of the origin of the strains (Sorum \& L'Abee-Lund, 2002). Bacteria isolated from animals carrying antibiotic resistance genes could contaminate food of animal origin and could transfer their resistance to food and then human microbiota (Sorum \& L'Abee-Lund, 2002). Modern industrialised food production adds extra emphasis on lowering the use of antibiotics in rearing domestic animals.

\section{QPS status or not?}

As underlined in this review, the main hazard of bacteria involved in food fermentation concerns antibiotic resistance. However and as adopted by EFSA (2005b), intrinsic resistance and resistance due to mutation of chromosomal genes present low risk of horizontal dissemination and such strains should be acceptable for consumption. While acquired resistance by mobile elements may present a risk for public health, safety assessment of starter strains should focus on antibiotic profile and transferable genetic determinants. The QPS status has been proposed for 32 selected species of Lactobacillus including the main species either found in naturally fermented sausages or added as starter cultures in meat products (EFSA, 2005a, 2005b). Regarding Pediococcus, $P$. acidilactici and $P$. pentosaceus used as starter culture are proposed for QPS status. Similarly, S. xylosus and S. carnosus used as starter culture are proposed for QPS status. While the Enterococcus genus is not proposed for the QPS status and a case-by-case evaluation of the potential of starter bacterial strain should be adopted.

\section{Acknowledgement}

The authors thank M. Desvaux for critical review and B. Duclos for secretarial assistance.

\section{References}

Albano, H., van Reenen, C. A., Todorov, S. D., Cruz, D., Fraga, L., Hogg, T., et al. (2009). Phenotypic and genetic heterogeneity of lactic acid bacteria isolated from "Alheira", a traditional fermented sausage produced in Portugal. Meat Science, 82(3), 389-398.

Ammor, M. S., \& Mayo, B. (2007). Selection criteria for lactic acid bacteria to be used as functional starter cultures in dry sausage production: An update. Meat Science, 76 (1), 138-146.

Ansorena, D., Montel, M. C., Rokka, M., Talon, R., Eerola, S., Rizzo, A., et al. (2002). Analysis of biogenic amines in northern and southern European sausages and role of flora in amine production. Meat Science, 61(2), 141-147.

Aymerich, T., Martin, B., Garriga, M., \& Hugas, M. (2003). Microbial quality and direct PCR identification of lactic acid bacteria and nonpathogenic Staphylococci from artisanal low-acid sausages. Applied and Environmental Microbiology, 69(8), 4583-4594.

Aymerich, T., Martín, B., Garriga, M., Vidal-Carou, M. C., Bover-Cid, S., \& Hugas, M. (2006). Safety properties and molecular strain typing of lactic acid bacteria from slightly fermented sausages. Journal of Applied Microbiology, 100(1), 40-49.

Baba, T., Takeuchi, F., Kuroda, M., Yuzawa, H., Aoki, K., Oguchi, A., et al. (2002). Genome and virulence determinants of high virulence community-acquired MRSA. Lancet, 359(9320), 1819-1827.

Bautista, L., Gaya, P., Medina, M., \& Nunez, M. (1988). A quantitative study of enterotoxin production by sheep milk staphylococci. Applied and Environmental Microbiology, 54(2), 566-569.

Benito, M. J., Martín, A., Aranda, E., Pérez-Nevado, F., Ruiz-Moyano, S., \& Córdoba, M. G. (2007). Characterization and selection of autochthonous lactic acid bacteria isolated from traditional Iberian dry-fermented salchichón and chorizo sausages. Journal of Food Science, 72(6), M193-M201.

Benito, M. J., Serradilla, M. J., Ruiz-Moyano, S., Martín, A., Pérez-Nevado, F., \& Córdoba, M. G. (2008). Rapid differentiation of lactic acid bacteria from autochthonous fermentation of Iberian dry-fermented sausages. Meat Science, 80(3), 656-661.

Bernardeau, M., Vernoux, J. P., Henri-Dubernet, S., \& Gueguen, M. (2008). Safety assessment of dairy microorganisms: The Lactobacillus genus. International Journa of Food Microbiology, 126(3), 278-285.

Biavasco, F., Giovanetti, E., Miele, A., Vignaroli, C., Facinelli, B., \& Varaldo, P. E. (1996). In vitro conjugative transfer of VanA vancomycin resistance between Enterococci and Listeriae of different species. European Journal of Clinical Microbiology E Infectious Diseases, 15(1), 50-59.

Blaiotta, G., Ercolini, D., Pennacchia, C., Fusco, V., Casaburi, A., Pepe, O., et al. (2004a) PCR detection of staphylococcal enterotoxin genes in Staphylococcus spp. strains isolated from meat and dairy products. Evidence for new variants of seG and seI in S. aureus AB-8802. Journal of Applied Microbiology, 97(4), 719-730.

Blaiotta, G., Pennacchia, C., Villani, F., Ricciardi, A., Tofalo, R., \& Parente, E. (2004b). Diversity and dynamics of communities of coagulase-negative staphylococci in traditional fermented sausages. Journal of Applied Microbiology, 97(2), 271-284.

Bonomo, M. G., Ricciardi, A., Zotta, T., Parente, E., \& Salzano, G. (2008). Molecular and technological characterization of lactic acid bacteria from traditional fermented sausages of Basilicata region (Southern Italy). Meat Science, 80(4), 1238-1248.

Bonomo, M. G., Ricciardi, A., Zotta, T., Sico, M. A., \& Salzano, G. (2009). Technological and safety characterization of coagulase-negative staphylococci from traditionally fermented sausages of Basilicata region (Southern Italy). Meat Science, 83(1), 15-23.

Bover-Cid, S., Hugas, M., Izquierdo-Pulido, M., \& Vidal-Carou, M. C. (2001). Amino aciddecarboxylase activity of bacteria isolated from fermented pork sausages. International Journal of Food Microbiology, 66(3), 185-189.

Chaillou, S., Daty, M., Baraige, F., Dudez, A. M., Anglade, P., Jones, R., et al. (2009). Intraspecies genomic diversity and natural population structure of the meat-borne lactic acid bacterium Lactobacillus sakei. Applied And Environmental Microbiology, 75 (4), 970-980.

Chamba, J. F., \& Jamet, E. (2008). Contribution to the safety assessment of technological microflora found in fermented dairy products - Introduction. International Journal of Food Microbiology, 126(3), 263-266.

Cocconcelli, P. S., Cattivelli, D., \& Gazzola, S. (2003). Gene transfer of vancomycin and tetracycline resistances among Enterococcus faecalis during cheese and sausage fermentations. International Journal of Food Microbiology, 88(2-3), 315-323.

Cocolin, L., Dolci, P., Rantsiou, K., Urso, R., Cantoni, C., \& Comi, G. (2009). Lactic acid bacteria ecology of three traditional fermented sausages produced in the North of Italy as determined by molecular methods. Meat Science, 82(1), 125-132.

Cocolin, L., Manzano, M., Aggio, D., Cantoni, C., \& Comi, G. (2001). A novel polymerase chain reaction (PCR)-denaturing gradient gel electrophoresis (DGGE) for the identification of Micrococcaceae strains involved in meat fermentations. Its application to naturally fermented Italian sausages. Meat Science, 58(1), 59-64.

Comi, G., Urso, R., Iacumin, L., Rantsiou, K., Cattaneo, P., Cantoni, C., et al. (2005). Characterisation of naturally fermented sausages produced in the North East of Italy. Meat Science, 69, 381-392.

Corbière Morot-Bizot, S., Leroy, S., \& Talon, R. (2006). Staphylococcal community of a small unit manufacturing traditional dry fermented sausages. International Journal of Food Microbiology, 108(2), 210-217.

Corbière Morot-Bizot, S., Leroy, S., \& Talon, R. (2007). Monitoring of staphylococcal starters in two French processing plants manufacturing dry fermented sausages. Journal of Applied Microbiology, 102(1), 238-244.

Corbière Morot-Bizot, S., Talon, R., \& Leroy, S. (2004). Development of a multiplex PCR for the identification of Staphylococcus genus and four staphylococcal species isolated from food. Journal of Applied Microbiology, 97(5), 1087-1094.

Coton, E., Desmonts, M. H., Leroy, S., Coton, M., Jamet, E., Christieans, S., et al. (2010). Biodiversity of coagulase-negative Staphylococci in French cheeses, dry fermented sausages, processing environments and clinical samples. International Journal of Food Microbiology, 137(2-3), 221-229.

Dordet-Frisoni, E., Dorchies, G., De Araujo, C. Talon, R., \& Leroy, S. (2007). Genomic diversity in Staphylococcus xylosus. Applied and Environmental Microbiology, 73(22), 7199-7209

Dupuis, A., Hennekinne, J. A., Garin, J., \& Brun, V. (2008). Protein standard absolute quantification (PSAQ) for improved investigation of staphylococcal food poisoning outbreaks. Proteomics, 8(22), 4633-4636.

EFSA. (Regulation (EC) $\left.n^{\circ} 178 / 2002\right)$. (2002). Regulation (EC) $n^{\circ} 178 / 2002$ of the European parliament and of the council of 28 January 2002 laying down the general principles and requirements of food law, establishing the European food safety authority and laying down procedures in matters of food safety. Official journal $L$ $31 / 1,01 / 02 / 2002$.

EFSA (2004). Scientific colloquium summary report: Qualified Presumption of Safety of microorganisms in food and Feed. http://www.efsa.europa.eu/fr

EFSA (2005a). Opinion of the Scientific Committee on a request from EFSA related to a generic approach to the safety assessment by EFSA of microorganisms used in food/ feed and the production of food/feed additives. The EFSA Journal, 226, 1-12.

EFSA (2005b). Opinion of the Scientific Panel on Additives and Products or Substances used in Animal Feed on the updating of the criteria used in the assessment of bacteria for resistance to antibiotics of human or veterinary importance. The EFSA Journal, 223, 1-12.

Even, S., Leroy, S., Charlier, C., Ben Zakour, N., Chacornac, J. P., Lebert, I., et al. (2010) Low occurrence of safety hazards in coagulase negative staphylococci isolated from fermented foodstuffs. International Journal of Food Microbiology, 139(1-2), 87-95. 
Garg, S. K., \& Mital, B. K. (1991). Enterococci in milk and milk-products. Critical Reviews in Microbiology, 18(1), 15-45.

Gevers, D., Masco, L., Baert, L., Huys, G., Debevere, J., \& Swings, J. (2003). Prevalence and diversity of tetracycline resistant lactic acid bacteria and their tet genes along the process line of fermented dry sausages. Systematic and Applied Microbiology, 26(2), $277-283$

Giammarinaro, P., Leroy, S., Chacornac, J. -P., Delmas, J., \& Talon, R. (2005). Development of a new oligonucleotide array to identify staphylococcal strains at species level. Journal Of Clinical Microbiology, 43(8), 3673-3680.

Greco, M., Mazette, R., De Santis, E. P. L., Corona, A., \& Cosseddu, A. M. (2005). Evolution and identification of lactic acid bacteria isolated during the ripening of Sardinian sausages. Meat Science, 69, 733-739.

Hugas, M., Garriga, M., \& Aymerich, M. T. (2003). Functionality of enterococci in meat products. International Journal of Food Microbiology, 88(2-3), 223-233.

Hummel, A. S., Hertel, C., Holzapfel, W. H., \& Franz, C. M. A. P. (2007). Antibiotic resistances of starter and probiotic strains of lactic acid bacteria. Applied and Environmental Microbiology, 73(3), 730-739.

Huys, G., D'Haene, K., Collard, J. M., \& Swings, J. (2004). Prevalence and molecular characterization of tetracycline resistance in Enterococcus isolates from food Applied and Environmental Microbiology, 70(3), 1555-1562.

Iacumin, L., Comi, G., Cantoni, C., \& Cocolin, L. (2006). Ecology and dynamics of coagulase-negative cocci isolated from naturally fermented Italian sausages. Systematic and Applied Microbiology, 29(6), 480-486.

Irlinger, F. (2008). Safety assessment of dairy microorganisms: Coagulase-negative staphylococci. International Journal of Food Microbiology, 126(3), 302-310.

Kastner, S., Perreten, V., Bleuler, H., Hugenschmidt, G., Lacroix, C., \& Meile, L. (2006). Antibiotic susceptibility patterns and resistance genes of starter cultures and probiotic bacteria used in food. Systematic and Applied Microbiology, 29(2), 145-155.

Latorre-Moratalla, M. L., Bover-Cid, S., Talon, R., Aymerich, T., Garriga, M., Zanardi, E. et al. (2010). Distribution of aminogenic activity among potential autochthonous starter cultures for dry fermented sausages. Journal of Food Protection, 73(3), 524-528.

Latorre-Moratalla, M. L., Veciana-Nogues, T., Bover-Cid, S., Garriga, M., Aymerich, T., Zanardi, E., et al. (2008). Biogenic amines in traditional fermented sausages produced in selected European countries. Food Chemistry, 107(2), 912-921.

Le Loir, Y., Baron, F., \& Gautier, M. (2003). Staphylococcus aureus and food poisoning. Genetics and Molecular Research, 2(1), 63-76.

Lebert, I., Leroy, S., \& Talon, R. (2007). Microorganisms in traditional fermented meats In F. Toldra, W.-K. Nip, J.G. Sebranek, L.H. Stahnke, Expedito T. F. Silvera, R. Talon (the Associate Editor) \& Y.H. Hui (Administrative Editor) (Eds.), Handbook of Fermented Meat and Poultry (pp. 113-124).

Leroy, S., Giammarinaro, P., Chacornac, J. P., Lebert, I., \& Talon, R. (2010). Biodiversity of indigenous staphylococci of naturally fermented dry sausages and manufacturing environments of small-scale processing units. Food Microbiology, 27(2), 294-301.

Leroy, S., Lebert, I., Chacornac, J. -P., Chavant, P., Bernardi, T., \& Talon, R. (2009). Genetic diversity and biofilm formation of Staphylococcus equorum isolated from naturally fermented sausages and their manufacturing environment. International Journal of Food Microbiology, 134, 45-51.

Leroy, F., Verluyten, J., \& De Vuyst, L. (2006). Functional meat starter cultures for improved sausage fermentation. International Journal of Food Microbiology, 106(3) 270-285.

Lund, B., \& Edlund, C. (2001). Probiotic Enterococcus faecium strain is a possible recipient of the vanA gene cluster. Clinical Infectious Diseases, 32(9), 1384-1385.

Martin, B., Garriga, M., Hugas, M., \& Aymerich, T. (2005). Genetic diversity and safety aspects of enterococci from slightly fermented sausages. Journal of Applied Microbiology, 98(5), 1177-1190.

Martín, B., Garriga, M., Hugas, M., Bover-Cid, S., Veciana-Nogues, M. T., \& Aymerich, T. (2006). Molecular, technological and safety characterization of gram-positive catalase-positive cocci from slightly fermented sausages. International Journal of Food Microbiology, 107, 148-158.

Mater, D. D. G., Langella, P., Corthier, G., \& Flores, M. J. (2005). Evidence of vancomycin resistance gene transfer between enterococci of human origin in the gut of mice harbouring human microbiota. The Journal of Antimicrobial Chemotherapy, 56(5), 975-978.

Mauriello, G., Casaburi, A., Blaiotta, G., \& Villani, F. (2004). Isolation and technological properties of coagulase negative staphylococci from fermented sausages of Southern Italy. Meat Science, 67(1), 149-158.

Mauriello, G., Moschetti, G., Villani, F., Blaiotta, G., \& Coppola, S. (2000). Antibiotic resistance of coagulase-negative staphylococci isolated from artisanal Naples-type salami. International Journal of Food Science and Nutrition, 51(1), 19-24.

Mogensen, G., Salminen, S., O'Brien, J., Ouwehand, A., Hozapfel, W., Short, C., et al. (2002). Food microorganisms: Health benefits a safety evaluation of certain food components. Bulletin of the IDF, 377, 4-9.

Moubareck, C., Bourgeois, N., Courvalin, P., \& Doucet-Populaire, F. (2003). Multiple antibiotic resistance gene transfer from animal to human enterococci in the digestive tract of gnotobiotic mice. Antimicrobial Agents and Chemotherapy, 47(9) 2993-2996.

Novakova, D., Sedlacek, I., Pantucek, R., Stetina, V., Svec, P., \& Petras, P. (2006) Staphylococcus equorum and Staphylococcus succinus isolated from human clinical specimens. Journal of Medical Microbiology, 55(Pt 5), 523-528.
Ogier, J. C., \& Serror, P. (2008). Safety assessment of dairy microorganisms: The Enterococcus genus. International Journal of Food Microbiology, 126(3), 291-301.

Papamanoli, E., Tzanetakis, N., Litopoulou-Tzanetaki, E., \& Kotzekidou, P. (2003). Characterization of lactic acid bacteria isolated from a Greek dry-fermented sausage in respect of their technological and probiotic properties. Meat Science, 65 (2), 859-867.

Piette, A., \& Verschraegen, G. (2009). Role of coagulase-negative staphylococci in human disease. Veterinary Microbiology, 134(1-2), 45-54.

Rantsiou, K., \& Cocolin, L. (2006). New developments in the study of the microbiota of naturally fermented sausages as determined by molecular methods: A review. International Journal of Food Microbiology, 108(2), 255-267.

Rantsiou, K., Drosinos, E. H., Gialitaki, M., Urso, R., Krommer, J., Gasparik-Reichardt, J., et al. (2005). Molecular characterization of Lactobacillus species isolated from naturally fermented sausages produced in Greece, Hungary and Italy. Food Microbiology, 22, 19-28.

Resch, M., Nagel, V., \& Hertel, C. (2008). Antibiotic resistance of coagulase-negative staphylococci associated with food and used in starter cultures. International Journal of Food Microbiology, 127(1-2), 99-104.

Rodriguez, M., Nunez, F., Cordoba, J., Bermudez, E., \& Asensio, M. (1996). Gram-positive, catalase-positive cocci from dry cured Iberian ham and their enterotoxigenic potential. Applied and Environmental Microbiology, 62(6), 1897-1902.

Rosec, J. P., Guiraud, J. P., Dalet, C., \& Richard, N. (1997). Enterotoxin production by staphylococci isolated from foods in France. International Journal of Food Microbiology, 35(3), 213-221.

Rossi, F., Tofalo, R., Torriani, S., \& Suzzi, G. (2001). Identification by 16S-23S rDNA intergenic region amplification, genotypic and phenotypic clustering of Staphylococcus xylosus strains from dry sausages. Journal of Applied Microbiology, 90(3), 365-371.

Seitter, M., Nerz, C., Rosenstein, R., Götz, F., \& Hertel, C. (2011). DNA microarray based detection of genes involved in safety and technologically relevant properties of food associated coagulase-negative staphylococci. International Journal of Food Microbiology, 145(2-3), 449-458.

Silvestri, G., Santarelli, S., Aquilanti, L., Beccaceci, A., Osimani, A., Tonucci, F., et al. (2007). Investigation of the microbial ecology of Ciauscolo, a traditional Italian salami, by culture-dependent techniques and PCR-DGGE. Meat Science, 77(3), 413-423.

Simeoni, D., Rizzotti, L., Cocconcelli, P., Gazzola, S., Dellaglio, F., \& Torriani, S. (2008). Antibiotic resistance genes and identification of staphylococci collected from the production chain of swine meat commodities. Food Microbiology, 25(1), 196-201.

Sorum, H., \& L'Abee-Lund, T. M. (2002). Antibiotic resistance in food-related bacteria A result of interfering with the global web of bacterial genetics. International Journal of Food Microbiology, 78(1-2), 43-56.

Stevens, N. T., Tharmabala, M., Dillane, T., Greene, C. M., O'Gara, J. P. \& Humphreys, H. (2008). Biofilm and the role of the ica operon and aap in Staphylococcus epidermidis isolates causing neurosurgical meningitis. Clinical Microbiology and Infection, 14(7), 719-722.

Suzzi, G., \& Gardini, F. (2003). Biogenic amines in dry fermented sausages: A review. International Journal of Food Microbiology, 88(1), 41-54.

Talon, R., Leroy-Sétrin, S., \& Fadda, S. (2002). Bacterial starters involved in the quality of fermented meat products - Chapter 10. In Toldrá Fidel (Ed.), Research advances in quality of meat and meat products (pp. 175-191). Research Signpost.

Tenover, F. C., \& McDonald, L. C. (2005). Vancomycin-resistant staphylococci and enterococci: Epidemiology and control. Current Opinion in Infectious Diseases, 18(4), 300-305.

Teuber, M., Meile, L., \& Schwarz, F. (1999). Acquired antibiotic resistance in lactic acid bacteria from food. Antonie Van Leeuwenhoek International Journal of General and Molecular Microbiology, 76(1), 115-137.

Vernozy-Rozand, C., Mazuy, C., Prevost, G., Lapeyre, C., Bes, M., Brun, Y., et al. (1996). Enterotoxin production by coagulase-negative staphylococci isolated from goats' milk and cheese. International Journal of Food Microbiology, 30(3), 271-280.

Villard, L., Maurin, F., Borges, E., Lacheretz, A., Richard, Y., \& Kodjo, A. (2003). Performance of Random Amplified Polymorphic DNA (RAPD) analysis and Pulsed Field Gel Electrophoresis (PFGE) for the characterisation of Staphylococcus xylosus strains. Revue de Médecine Vétérinaire, 154(1), 47-50.

Weckx, S., Allemeersch, J., Van der Meulen, R., Vrancken, G., Huys, G., Vandamme, P., et al. (2009). Development and validation of a species-independent functional gene microarray that targets lactic acid bacteria. Applied and Environmental Microbiology, 75(20), 6488-6495.

Willems, R. J. L., Top, J., van Santen, M., Robinson, D. A., Coque, T. M., Baquero, F., et al. (2005). Global spread of vancomycin-resistant Enterococcus faecium from distinct nosocomial genetic complex. Emerging Infectious Diseases, 11(6), 821-828.

Zell, C., Resch, M., Rosenstein, R., Albrecht, T., Hertel, C., \& Gotz, F. (2008). Characterization of toxin production of coagulase-negative staphylococci isolated from food and starter cultures. International Journal of Food Microbiology, 127(3), 246-251.

Zonenschain, D., Rebecchi, A., \& Morelli, L. (2009). Erythromycin- and tetracyclineresistant lactobacilli in Italian fermented dry sausages. Journal of Applied Microbiology, 107(5), 1559-1568. 